\title{
An Empirical Study on the Evaluation of the Performance of Private Universities
}

\author{
Aihua Zhang \\ Department of economics and management, Wenhua College \\ aiwa0716@163.com
}

Keywords: Private colleges and universities; Performance appraisal; Evaluating indicator; Weight

\begin{abstract}
With the continuous expansion of enrollment in private colleges and universities and the expansion of private universities' scale, China's private universities has been exposed to the shortage of education funds and the decline of teaching quality, especially the performance evaluation problem, which has aroused widespread concern in society. Based on the comprehensive research results at home and abroad, this paper establishes the performance evaluation index system of private universities and discusses how to scientifically evaluate the performance of private universities, just take a private university as an example, aiming at improving the utilization rate of higher education resources and promoting the rapid and healthy development of private universities.
\end{abstract}

\section{Introduction}

The higher education of our country has already entered the stage of popular development recognized. Despite the establishment and expansion of private colleges has tackled the contradiction between unbalance of supply and demand of China's higher education to a certain extent, and stimulated the economic development of our country, China's private universities in the educational quality and students' employment has also exposed some problems in that the teaching funds is not sufficient enough and the teaching management is not reasonable [1]. Under this background, it is of practical significance to study the performance evaluation of private colleges and universities to improve the efficiency of private colleges and universities, and promote the healthy development of private colleges. Therefore, the performance evaluation is a critical chain in the management of private colleges. The establishment of performance evaluation system of private colleges and universities to develop qualitative and quantitative key performance indicators, in order to comprehensively improve the performance evaluation and management of private colleges and universities, which is the focus of this paper to study.

\section{The Domestic and Foreign Research Status Quo of University Performance Evaluation}

Developed countries in the world attach great importance to the study on the evaluation of educational performance. Performance evaluation for schools in the United States began since 1966 Coleman's report. At present, many states have already implemented higher education accountability composed of performance report, the performance budget and funding. These three kinds of performance policy are inseparable from the performance evaluation of colleges and Universities. In 1980s, a joint working group of the British vice president and the president of the association and the University Grants Committee classify performance indicators into input indicators, process indicators and output indicators [2,3]. The Holland government investment in higher education also take the performance evaluation as a prerequisite. The National Center for education and the National Science Council, Australia University Vice Chancellor and President of the Commission, Holland Committee of higher education science and the economic cooperation organization of higher education evaluation index have carried out extensive research and application in education management.

Our research work on performance evaluation of university has experienced from scratch, from the qualitative to the combination of qualitative and quantitative tools, from a single evaluation to process 
multi-tool combination evaluation. The understanding of the relevant research on the problem of the performance evaluation, started from the preliminary realization of the importance to the development of the extensive and detailed discussion and practice operation stage. In recent years, the research on performance evaluation and evaluation methods put great emphasis on the construction and application of the index system. For example, in view of the present situation of the performance evaluation of college teachers and combined with the actual situation of local colleges and universities, Gu Jiantao and so on (2007) established the index system of the performance evaluation of teachers in Colleges and universities; Zhu Wei and Zhang Xiaolin (2009) believes that the Balanced Scorecard in university financial evaluation index including basic analysis index, comprehensive index analysis of two parts, and they take a university as an example of empirical data analysis; Wei Bin (2012) made analysis and evaluation of scientific research performance, and put forward the corresponding improvement suggestions for college, by using DEA method, taking the two colleges of a university as a decision making unit, taking the number of personnel, scientific research investment as input indicators, scientific research achievements as output indicators [4]. The research on performance evaluation of higher school is mostly centered on the research university but paid little attention to the private university of university performance evaluation.

There is a wide gap between private universities in teaching and scientific research level and research university, thus the performance evaluation index of research universities cannot be directly applied to private colleges, it is necessary to construct private universities performance evaluation index system according to their characteristics.

\section{An Empirical Study on the Evaluation of the Performance of Private Universities}

The Performance Evaluation Index System of Private Universities. Performance evaluation of civilian run colleges and universities should fully reflect the capital efficiency and effectiveness of the use in civilian run colleges and universities, in accordance with this line of thought, according to the level of thinking, combined with characteristics of the civilian run colleges and universities. In this paper the evaluation content is divided into two level indexes. The first level is the four basic modules, namely, the ability to raise funds in colleges and universities, the output efficiency of funds, the use of funds efficiency and the development potential of colleges and universities. Among them: the ability to raise funds in colleges and universities is to assess the adequacy of education funding for private colleges, including tuition revenue growth rate, income generating capacity, three indicators of teacher per capita scientific research funds; the output efficiency of financial funds is mainly reflected by cultivating students' quantity and quality, the results of scientific research in quantity and quality and achievements transformation content ,including million yuan financial investment in training students and teachers per capital, publishing papers and monographs number per faculty [5], research achievement award and the patent number and the transformation rate of scientific research results of four indicators; efficiency in the use of funds mainly consider the evaluation object internal resources allocation and use efficiency, including the ratio of students to teachers, teachers accounted for the ratio of all teaching and administrative staff, business expenses, equipment purchase costs accounted for the proportion of public expenditure of three indicators; the potential for the development of colleges and universities mainly reflects the whether the funds is used for long-term development or promotion of school brand and expand the influence or used for the development of the school to have plenty of stamina infrastructure, including full-time teachers with the proportion of doctoral and master's degree, continuous two years education funds income average growth rate and the continuous three years graduate employment rate and the growth rate of total assets etc.

The Performance Evaluation Index of Private Colleges Dimensionless. The performance evaluation of private colleges and universities adopts percentile scoring method. In the original index system, the index is not uniform [6], some numerical index difference reaches tens of thousands, and some differences in index only digits on the raw data of these different dimensions with different characteristics cannot be directly used for statistical analysis, so in the statistics analysis before the 
first to eliminate the influence of the dimension, making the data comparable. The case transfers the original data of different evaluation indexes of the following values into evaluation score percentile by using the evaluation index and conversion efficiency coefficient method. See Table 1.

Table 1 Evaluation index dimensionless conversion table [7]

\begin{tabular}{|c|c|c|c|}
\hline \multicolumn{2}{|r|}{ evaluating indicator } & \multirow{2}{*}{$\begin{array}{l}\text { The } \\
\text { evaluation } \\
\text { index value } \\
5.22\end{array}$} & \multirow{2}{*}{$\begin{array}{l}\text { Use efficacy } \\
\text { coefficient method } \\
\text { to calculate score } \\
78.25\end{array}$} \\
\hline \multirow{3}{*}{$\begin{array}{l}\text { Fund raising } \\
\text { ability }\end{array}$} & Tuition revenue growth rate $(\%)$ & & \\
\hline & Revenue generating capacity (\%) & 6.18 & 63.50 \\
\hline & $\begin{array}{l}\text { Teachers per capita scientific } \\
\text { research funds ( } 10000 \text { yuan })\end{array}$ & 3.23 & 65.45 \\
\hline \multirow{4}{*}{$\begin{array}{l}\text { Capital } \\
\text { output } \\
\text { efficiency }\end{array}$} & $\begin{array}{l}\text { Ten thousand yuan financial } \\
\text { investment to cultivate the } \\
\text { number of students(a) }\end{array}$ & 2.65 & 70.42 \\
\hline & $\begin{array}{l}\text { The number of published papers } \\
\text { (article) }\end{array}$ & 1.39 & 62.40 \\
\hline & $\begin{array}{l}\text { Number of teachers per capita } \\
\text { scientific research achievements } \\
\text { (a) }\end{array}$ & 7.68 & 55.78 \\
\hline & $\begin{array}{l}\text { Application conversion rate of } \\
\text { scientific research achievements } \\
(\%)\end{array}$ & 11.43 & 62.40 \\
\hline \multirow{3}{*}{$\begin{array}{l}\text { Efficiency of } \\
\text { fund use }\end{array}$} & Student teacher ratio $(\%)$ & 21.18 & 75.55 \\
\hline & $\begin{array}{l}\text { All the staff of full-time teachers } \\
\text { accounted for the proportion }(\%)\end{array}$ & 46.22 & 73.25 \\
\hline & $\begin{array}{l}\text { Proportion of business expenses } \\
\text { and equipment purchase } \\
\text { expenses }(\%)\end{array}$ & 48.90 & 72.60 \\
\hline \multirow{4}{*}{$\begin{array}{c}\text { development } \\
\text { potential }\end{array}$} & $\begin{array}{l}\text { Full-time teachers jozo doctoral } \\
\text { ratio }(\%)\end{array}$ & 67.65 & 92.35 \\
\hline & $\begin{array}{l}\text { Education expenditure growth } \\
\text { rate }(\%)\end{array}$ & 2.45 & 72.78 \\
\hline & Total asset growth rate $(\%)$ & 0.47 & 50.70 \\
\hline & Graduate employment rate $(\%)$ & 52.65 & 64.01 \\
\hline
\end{tabular}


Weight Assignment Performance Evaluation Index of Private Colleges. After the dimensionless treatment of the above evaluation indexes based on the efficacy coefficient method and the transformation of 14 evaluation index weight according to the ideological level[8]. It can be calculated that the relative weighting of each indicator after each evaluation index percentile scores through the use of expert advice or judgment based on experience to construct five pairwise comparison judgment matrix. Results are shown in Table 2.

Table 2 Evaluation index weight assignment table

\begin{tabular}{|c|c|c|c|}
\hline $\begin{array}{c}\text { First level } \\
\text { evaluation index }\end{array}$ & weight & Second level evaluation index & weight \\
\hline \multirow{3}{*}{ Fund raising ability } & \multirow{3}{*}{0.27} & Tuition revenue growth rate $(\%)$ & 0.55 \\
\hline & & Revenue generating capacity $(\%)$ & 0.23 \\
\hline & & $\begin{array}{l}\text { Teachers per capita scientific } \\
\text { research funds ( } 10000 \text { yuan })\end{array}$ & 0.22 \\
\hline \multirow{4}{*}{$\begin{array}{l}\text { Capital output } \\
\text { efficiency }\end{array}$} & \multirow{4}{*}{0.25} & $\begin{array}{l}\text { Ten thousand yuan of funds into the } \\
\text { training of the number of students (a) }\end{array}$ & 0.48 \\
\hline & & $\begin{array}{l}\text { The number of published papers } \\
\text { (article) }\end{array}$ & 0.19 \\
\hline & & $\begin{array}{l}\text { Number of teachers per capita } \\
\text { scientific research achievements (a) }\end{array}$ & 0.15 \\
\hline & & $\begin{array}{l}\text { Application conversion rate of } \\
\text { scientific research achievements }(\%)\end{array}$ & 0.18 \\
\hline \multirow{3}{*}{$\begin{array}{l}\text { Efficiency of fund } \\
\text { use }\end{array}$} & \multirow{3}{*}{0.26} & Student teacher ratio $(\%)$ & 0.42 \\
\hline & & $\begin{array}{l}\text { All the staff of full-time teachers } \\
\text { accounted for the proportion }(\%)\end{array}$ & 0.26 \\
\hline & & $\begin{array}{l}\text { Proportion of business expenses and } \\
\text { equipment purchase expenses }(\%)\end{array}$ & 0.32 \\
\hline \multirow{4}{*}{$\begin{array}{l}\text { development } \\
\text { potential }\end{array}$} & \multirow{4}{*}{0.22} & $\begin{array}{l}\text { Full-time teachers jozo doctoral ratio } \\
(\%)\end{array}$ & 0.30 \\
\hline & & $\begin{array}{l}\text { Education expenditure growth rate } \\
(\%)\end{array}$ & 0.30 \\
\hline & & Total asset growth rate $(\%)$ & 0.19 \\
\hline & & Graduate employment rate $(\%)$ & 0.21 \\
\hline
\end{tabular}

Performance Evaluation Results of Private Colleges and Universities. After finishing the evaluation index dimensionless transformation and evaluation index weight assignment, according to the model of evaluation, score were calculated for each index score, finally a private college in performance evaluation score is calculated using the method of weighted comprehensive summation of the results for 70.98 points [9]. 


$$
X=\sum_{i=1}^{n} \sum_{j}^{n} \sum_{k}^{n} B_{i j}^{k} \bullet W_{i j}^{k}
$$

\section{Summary}

At present, there still exist many problems in the evaluation of the performance of private colleges and universities in our country, such as the index set is not perfect and standard setting is not exact, which leads to the results that performance evaluation process cannot meet the requirements of the private colleges and universities own management needs and social needs of private universities in the evaluation [10].

On the basis of the existing research results, this paper established the performance evaluation index system of private colleges and universities, and studied the performance evaluation of private universities.

Through evaluation ,it can not only make the multi-factor evaluation for private colleges and universities teaching, scientific research, for colleges and universities to recognize their own strengths and weaknesses and clear direction of development in the future ,but also can compare the performance in different, relevant policies so as to provide reference for government departments to formulate.

\section{Acknowledgements}

This paper is based on The Hubei Provincial Department of education of Humanities and social scientific research special task of project based on performance evaluation, BSC, transformation of the new private universities and colleges of undergraduate course -- in Mandarin, for example "(15Z163) stage research results.

\section{References}

[1] Phil Baty. The New Methodology of THE's World University Rankings [J]. Journal of International Higher Education, 2010, 3(4)

[2] Lei Zhong. Research on the performance evaluation of talent strategy in Universities in China [D]. Wuhan: Wuhan University of Technology, 2011

[3] Zheng Li. Application of balanced score card in the performance management of colleges and universities [J]. Journal of Tianjin University (SOCIAL SCIENCE EDITION), 2009, 11 (3).

[4] Zhang Lei, Zhang yanfei, Li Gui. Fiscal expenditure project performance evaluation index system design framework and its application [J], modern finance, 2008, (8)

[5] Maoyun Xue, Dade Yi. Jiangsu Province university educational investment performance evaluation discussion on -- Based on fuzzy comprehensive evaluation method $[\mathrm{J}]$. Modern economic information. 2010, (8)

[6] Wang Guangyan, Li Yuanyuan, Qiu Xueqing, Li Min. Empirical research and Thinking on the evaluation index system of College Teachers' performance $(J)$. Research on Higher Education in China, 2008, (2).

[7] Zhu Zhigang. Study on the performance evaluation of financial expenditure [M]. China financial and Economic Publishing House, 2006

[8] Jiang Tongtong. The concept of sustainable development and the research on the performance evaluation of $[\mathrm{J}]$. AHP in accounting and finance, based on the 2011, (4)

[9] Nie Feifei. Key Laboratory of colleges and universities scientific research performance evaluation method research -- Taking Chongqing Municipal Colleges and universities for example [D]. Chongqing: Chongqing Normal University, 2010

[10] Sholpan Kalanova. Ranking of Higher Education Institutions of Kazakhstan[J], Journal of International Higher Education, 2010, 3(4) 